\title{
From The Law Librarian to Legal Information Management, from Bulletin to Journal: a Jubilee Year
}

\begin{abstract}
Legal Information Management has reached 50 years since it was launched, under a different name, by the British and Irish Association of Law Librarians (BIALL). In this article the current editor of the journal, David Wills, reviews the history of the journal from its launch in spring 1970 when it took the name The Law Librarian, and describes how it has evolved, often reflecting the changing nature of the legal information profession in those intervening years. He follows the journey as this periodical developed from small beginnings, explains how it was enhanced by successive editors, why it became necessary to change its title in $200 \mathrm{I}$ and describes the move to the current publisher, Cambridge University Press in 2004. He reflects on the current status of the journal, as an electronic product while also retaining its profile in print and, finally, he draws attention to some possible challenges for the future.
\end{abstract}

Keywords: legal publishing; legal journals; law librarianship; legal information management; BIALL

\section{INTRODUCTION: BIALL'S JOURNAL}

This journal has reached its fiftieth birthday and this article marks and celebrates its contribution to the literature associated with law librarianship and legal information over the last five decades. Throughout its history, the journal has reflected both the changing world of law libraries and the shifting interests of legal information professionals. Primarily, it has been the journal of the British and Irish Association of Law Librarians (BIALL) but its reach has gone far beyond its members with a readership that is widespread and international in nature.

The journal has concerned itself with issues relating to the traditional law librarian often based in academia, the judiciary and the institutions associated with the practicing lawyer (such as the Inns of Court), and those working in government departments and Parliament. It has also reflected the growth of legal information professionals and specialists, knowledge managers and professional support lawyers who operate in the commercial sector (in law firms and legal units in the private company world). Throughout its history the content of the journal has focused on legal materials and the 'tools of the trade', both in print and in the electronic and digital resources that have emerged in the last 25 years or more, and on their management. It has continually focused on the changing legal publishing world and how the industry has been shaped by rapid technological advancement.

Over the last fifty years the journal has evolved considerably. It began life as The Law Librarian and then after some thirty years it morphed into the journal as it is today, Legal Information Management (sometimes abbreviated to LIM). Over that time some 1,650 , or so, substantive articles have been published (about 750 articles during its time as The Law Librarian (1970-2000) and around 900 in the re-named Legal Information Management (200I to 2019)).

I should preface this account by saying that this article is a personal view of the development of the journal and has been drafted having consulted many of the editorials, written by the editors, and by taking account of the content of the many volumes published since 1970. The article takes a chronological approach, often following the views and comments of the editors along the way, rather than looking at the administration behind the journal and from the journal's Editorial Board's perspective.

The editorship, in either an honorary or a paid capacity, has changed hands seven times during the history of the journal with six different editors each of whom were effectively commissioning editors who were responsible for masterminding both the content and, to a large 


\begin{tabular}{ll} 
Hon. Editors & \\
1970-1977: & Elizabeth Moys \\
1977-1984: & Donald Raistrick \\
1984-1990: & Barbara Tearle \\
1990-1995: & Christine Miskin \\
Editors & \\
1995-2002: & Laurence Eastham \\
2002-2011: & Christine Miskin \\
2011- & David Wills \\
\hline
\end{tabular}

Figure 1: The list of editors of The Law Librarian and Legal Information Management, 1970-2020.

extent, the direction of the journal albeit under the watchful eye of the Editorial Board. The quality of the publication has always been determined by the dedication and drive of the editors - it's a 'labour of love' as one former editor put it to me before I took on the role.

\section{THE LAW LIBRARIAN: SMALL BEGINNINGS}

Last year, 2019, BIALL celebrated its fiftieth anniversary. ' Within a year of the Association being established in 1969, there was a recognised need for a publication that would be identified with BIALL and with the law library profession in Britain and Ireland. ${ }^{2}$ Appropriately at the time, it was to be called The Law Librarian with the subtitle, Bulletin of the British and Irish Association of Law Librarians. It was decided that the first issue should be published by Easter 1970.

At BIALL's first Annual General Meeting Derek Way, one of the Association's founder members, was elected Honorary Editor of the newly proposed journal, though unfortunately he was unable to continue and had to resign almost immediately due to personal reasons. The editorial baton was immediately taken up with much zeal by another founder member, Elizabeth (Betty) M. Moys. The inaugural issue duly appeared in April 1970 with the legal publishers Butterworths and Sweet \& Maxwell providing assistance with the preparation and printing. Betty wrote a brief first editorial that began as follows:

The Executive Committee was very keen to get the process rolling for the first issue of The Law Librarian before the Association's first birthday. We have succeeded, but only by producing a rather small issue. We hope that it makes up in quality what it may seem to lack in quantity. The Committee aims initially to produce three issues each calendar year. As soon as the Association's finances permit, we intend to increase the number of pages in each issue and, perhaps, ultimately change to quarterly publication. ${ }^{3}$

The opening issue ran to twelve pages and contained two articles - one about the Liverpool University Law Library written by Derek Way, who was the Sub-Librarian of that library, and the other was entitled The Statutory Publications Office: Past, Present and Future which was written by A.B. Lyons, Editor of Statutory Instruments. The issue also included a number of other sections - a Members' Forum, Secretary's Notes, BIALL's constitution, and the Association's Rules and Regulations. B.J. Halevy, Law Librarian and Professor of Law at York University, Toronto wrote a review in the AALL Law Library Journal saying, '....and it is surprisingly good, considering the newness of the organisation'! ${ }^{4}$ The content of the first issue set the model. Derek Way's article on Liverpool University Law Library was an account of the law library as the venue for the first conference. For the next few years, the issue preceding the annual conference contained an article about the law library in the institution where the conference would be held. A.B. Lyons' article drew upon conference papers (a fruitful source for quality articles which is still used today), in this case on a paper he gave at the second BIALL Harrogate Workshop that was held in 1969, an event that led directly to the establishment of the Association.

In terms of other content, a regular feature from the beginning was the publication of 'official' BIALL statements, eg. Standards, memoranda submitted to other bodies, salary surveys, reports of internal surveys, eg. into academic law libraries.

With reference to the design, the masthead of the journal was attributed to Miss Diana Harris, a student in the Graphic Department at Goldsmiths' College, University of London, where Betty was Librarian. The initial design ran from volume I to volume 17. The coloured mastheads deliberately followed a sequence of red, green, blue and yellow, each colour to be used for the three issues of a volume before moving on to the next colour. The sequence began again at volume 5 . It continued to volume 17 (red) when the cover was re-designed. During this period the sub-title was Bulletin.

The Law Librarian was the first journal in the British Isles devoted to the subject of law librarianship. At the time of the first issue the Chairman of BIALL, Don Daintree, noted that it was 'only the third English-language journal in this field' after the Law Library Journal (of the American Association of Law Libraries) and the International Journal of Legal Information (the journal of the International Association of Law Libraries). ${ }^{5}$

The specific aim of The Law Librarian was to cover the interests and developments relating to practitioners working in the law libraries in Britain and Ireland. The profession, and indeed BIALL in its early days, looked very different then, compared with today. Then, many in the profession came from the academic library world and 


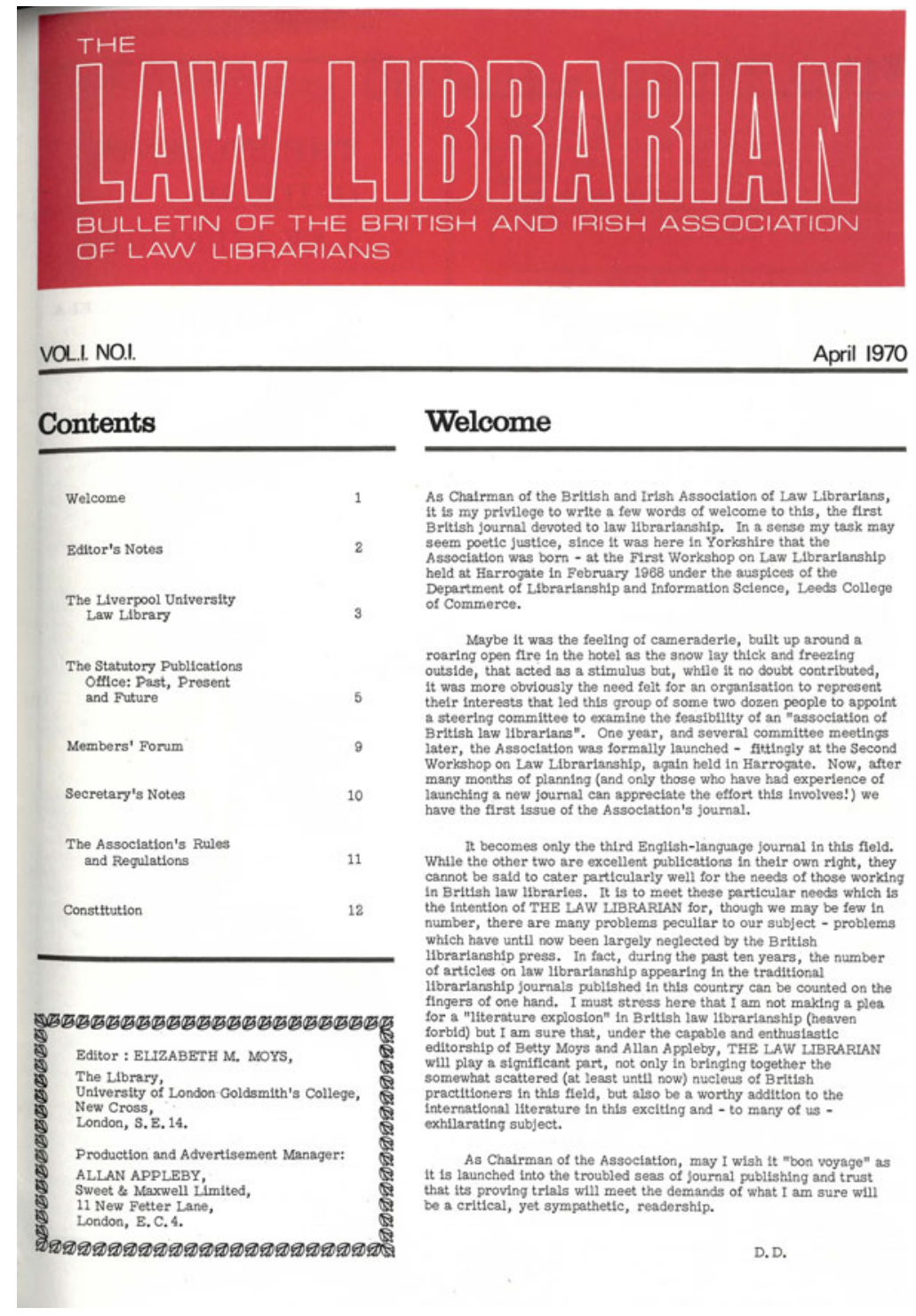

Figure 2: The first issue of The Law Librarian.

at this stage in its history BIALL was still a very small association. As Don expressed it in 1970:

...though we may be few in number, there are many problems peculiar to our subject - problems which have until now been largely neglected by the British librarianship press.

He continued, In fact, during the past ten years, the number of articles on law librarianship appearing in the traditional librarianship journals published in this country can be counted on the fingers of one hand.

The gap in the market needed filling and The Law Librarian was seen as a way of not only

bringing together the somewhat scattered ... nucleus of British [and Irish] practitioners in the field, but [would] also be $a$ worthy addition to the international literature in this exciting and - to many of us - exhilarating field. ${ }^{6}$

\section{GROWTH AND DEVELOPMENT}

BIALL and Sweet \& Maxwell agreed that the latter would publish the bulletin from 1971 onwards. Further agreements followed and the journal retained the same publisher until 2004.

Betty Moys continued as editor for seven years. The journal had a consistency about it with each of the three issues per year containing between two and four substantive articles together with a range of Association-related information, news and other short pieces. A glance across the front covers of the journal at this time reveals a contents listing that included items such as committee notes, proceedings of the BIALL AGM, rules of the Association, obituaries, book reviews, conference reports, a 'people in profile' section, book notes and 'letters to the editor' as well as a current awareness section. Perhaps alarmingly not only were the annual lists of BIALL members published as well as details of new members joining, there 
were also lists of 'lapsed members' (...presumably, as a result of subscriptions left unpaid!) - a public naming and shaming section, no less! In this regard, the publication was part journal for the profession and part newsletter for the Association - a bulletin for law librarianship. It was a highly informative product and successful from the start.

At this point, it is worth noting that the 1970s and 1980s were a very different era of communications compared to today. There was no instant dissemination of information via the internet, nor email. Only members, subscribers and people consulting it in libraries could see The Law Librarian and the personal information, as mentioned above, that it contained. As Barbara Tearle mentioned in conversation, 'finding out about events and people really was a game played on a different field. It was difficult to find out anything. The privacy of personal data was scarcely an issue at that time'.

In the early 1970s there were excellent and stimulating articles published and many which would bring enjoyment today. Some that I have noted while looking through the early issues were entitled: 'The Law in the Next Decade', 'Law Libraries and Law Collections in the Federal Republic of Germany'8, 'The Beginnings of legal journalism', 'Problems of Non-Legally Qualified Librarians in Law Libraries'10, 'The Provision of Books in the Courts of Scotland' " and 'Computers and Legal Publications'. 12

When Betty Moys retired from her editorship it was noted that, 'Betty Moys was Hon. Editor of The Law Librarian since its inception in 1969. It was her baby and she nurtured it during its birth and infancy; her enthusiasm never flagged.' ${ }^{3}$ BIALL members owe much to Betty Moys. Wallace Breem wrote, 'The success of any new journal is almost always largely due to the efforts of its first editor, for whom it becomes a work of devotion. Without any such enterprise it is almost certain to fail.' ${ }^{4}$

After Betty's tenure came to an end, The Law librarian continued from 1978 in the secure hands of the new Hon. Editor Donald (Don) Raistrick, then of the Law Commission Library and who would become well known in the future for his Index to Legal Citations and Abbreviations. The content and style of the journal continued in much the same vein over the course of a further eight years. While Betty Moys' achievement had been to launch and establish the journal, Don Raistrick's role was, in the words of Barbara Wells, 'to continue it as a medium for disseminating Association business and for providing interesting and varied articles on a widening range of professional law library concerns'. ${ }^{5}$ By this time the current awareness section had grown to an extensive and detailed format.

\section{A CHANGING PROFESSION}

Two major things were happening as the 1970s drew to a close and a new decade began. Firstly, the profession of law librarianship was starting to change. Secondly, computers and technology was beginning to have a major impact. The progress of the The Law Librarian mirrored these events accordingly. It is interesting to note the development of the professional issues being covered by the journal during this period. The more traditional role of the law librarian in institutions in academia and the professional bodies was still evident but other sectors, notably the commercial world, were starting to employ librarians too. As a reflection of the changing nature of the membership of BIALL, the growth in law librarianship among the law firms was starting to become very apparent and, in line with this, articles began appearing in The Law Librarian such as: 'Private Libraries in the City'16, 'The Solicitors' Law Firm Library'17 and 'The Use of Prestel in a Solicitor's Law Firm in the City'. ${ }^{18}$

\section{TECHNOLOGY AND LAW LIBRARIES}

The presence of technology was becoming more evident in law library business. Articles addressed 'Automation in the Law School Library'19, 'Technical Developments in Legal Information Retrieval'20, 'The Computer in Legal Education'2I and 'Legal Data Online'.22 The papers of the BIALL Annual Conference were published and the theme of the $16^{\text {th }}$ conference held in September 1985 at Manchester Polytechnic was devoted to the subject of 'Information Technology and Law Libraries'. From that event eight papers appeared in The Law Librarian, among them 'The 'Paperless law library' in the United States' ${ }^{23}$, 'The use of Microcomputers in libraries and information services'24 and 'POLIS: the Parliamentary Online Information Systems'. ${ }^{25}$ Clearly, computers and IT in law were here to stay and there was plenty to write about! It was also notable that articles were tending to become lengthy in term of their word count.

\section{THE MISSION OF THE LAW LIBRARIAN: A RESTATEMENT}

By the time that the third issue was published in 1984, Barbara Tearle (then Barbara Wells of the Library at University College London, later Librarian at the Bodleian Law Library, Oxford) had taken over the editorial reins from Don Raistrick and had become the third Hon. Editor of The Law Librarian. Often when editors assume the duties of editorship they outline their intentions. In her first editorial, Barbara reaffirmed the mission of the publication by stating:

The Law Librarian is the journal of BIALL, which was set up to encourage communication for mutual benefit amongst librarians working with legal materials in the British Isles. As such, The Law Librarian has a primary duty towards the members of the Association. It should report on Association activities ...... and discuss both librarianship and legal activities and technological developments in the British Isles which have $a$ bearing on the work of its members. It should inform members in one type of library about the work and problems in other types. It should consider the need of users of legal material and, when necessary, 
promote their interests. It should describe and comment on the literature of the law itself, to inform and educate its readers. ${ }^{26}$

Barbara also noted that by the time she took over as editor in 1984 The Law Librarian was read, not only by BIALL members and UK law librarians, but also by hundreds of other librarians in over forty countries and that the journal was catering for both overseas as well as home readers. She declared her focus to be to ensure coverage of such issues as: the legal work and publications of international organisations, methods and new formats of publishing, the rapidly developing world of computer technology as it affects law libraries and the growing international bibliographical control of legal literature. Barbara achieved these ambitions and much more and the amount of content contained in each issue increased; the April 1985 volume (16(I)) was a bumper issue and contained some 60 pages of content with nine articles as well as the extra content associated with the Association. The year 1983 had seen the launch of the BIALL Newsletter which meant that some of the Association-related issues were diverted to that publication and thus freed The Law Librarian to deliver substantive items more suited to a journal than a bulletin.

\section{REDESIGN AND EVOLUTION}

BIALL was evolving and the number of law librarians working in law firms had gathered more pace. According to Christine Miskin, writing in 1987, there were:

At least sixty firms in London employing professional librarians involving 150 people working in this branch of the profession. This [was] an increase of several hundred per cent over the past twelve years. ${ }^{27}$

Christine's article opened the first issue of The Law Librarian in 1987 and, as if to bring the image of the journal up-to-date and reflect the growth of the profession in the commercial sector, after eighteen years The Law Librarian was ready for a new design and a refreshed image. The front cover was changed as was the interior typeface and layout. An extra level of professionalism was evident and the enhancement to the physical quality of the publication was immediately obvious. The sub-title of 'Bulletin' was no longer used on the front cover.

As Barbara explained in conversation, she:

...cribbed the new maroon colour and the title in the white panel from the cover used for the publications of the Hertfordshire Record Society, because I liked it. The open book logo was also new. I also cribbed the contents listing on the back outside cover from another journal because it seemed a quick way for the reader to see the major content. As well as a new cover, the sub-title was altered from Bulletin to
Journal. This new look took effect from volume 18 , 1987.

Where the publishing process was concerned, the publisher Sweet \& Maxwell did remarkably little other than source advertisements for inclusion in the journal. The editor dealt directly with the printer for everything else.

The subject matter was changing too, moving with the times as ever. As in other sectors, management and strategic issues were coming to the fore. Relevant articles in the journal appeared such as 'Managing to improve: effective management of library and information services'28, 'Interpersonal skills in operational management'29, 'Industrial relations at work - law and literature'30 and 'Strategy for the Nineties: the Law Firm Perspective'. ${ }^{31}$ These were just some of the written pieces of the period that reflected the changing landscape. Of course, many of the traditional interests of the law librarians continued and were well represented with articles such as: 'Legislation in Northern Ireland'32, 'The Library and the Book Trade'33, 'Some Issues in Legal Indexing'34, 'Law libraries in Ireland'35 and 'Using TINlib for Cataloguing at Lincoln's Inn'. ${ }^{36}$

Barbara Tearle's last issue was for December 1990 and from April the next year the new Hon. Editor was Christine Miskin who fully acknowledged Barbara's very considerable contribution to the quality and evolution of the journal, writing that under her charge it had improved 'beyond all recognition' and acknowledging that she had 'imposed very high editorial standards'. ${ }^{37}$ From January 1992 BIALL Council had approved a number of changes to The Law Librarian with a new publishing cycle whereby there would be four issues per year (in March, June, September and December). The Newsletter would have a similar cycle but would appear midway between each issue of The Law Librarian in order to keep members up to date on Association and professional matters every few months. Again, it is important to realise that this was still an era where the dissemination of information was in published form; there were no blogs or tweets and email was in its early infancy.

As Christine wrote in her first editorial:

Production of the journal is being undertaken using the desktop publishing programme Ventura Publisher and this will allow shorter copy deadlines.

The content of both The Law Librarian and the Newsletter has been examined and it has been decided to drop altogether the Law Books Published and the Books received sections. The accounts will no longer be published in full. The salaries survey will appear as an Appendix to the Newsletter; details of new members will also appear in the Newsletter: as will the Professional Diary. ${ }^{38}$

The new BIALL house colours and logo meant that there was a different feel about the publication. By this time 
The Law Librarian had grown into a more substantial journal. Specific themes developed for individual issues and the tradition of publishing papers from the BIALL Annual Conference continued to be a standard feature. Guest editors were also commissioned and were making particular contributions. Christine continued Barbara's excellent eye for detail and her devotion to the quality of the content. Among some of the eye-catching articles from that period there were 'This Little Piggy Went to Market: a Case Study in Agricultural Law'39, 'Developing the Video collection in the Wolverhampton Polytechnic Law Library'40, 'The Barrington Manuscripts: from Durham to the Inner Temple'4I and 'The Bailiwick of Guernsey'42. I particularly liked the title 'From Cavalry to Courts - Impressions of Law Librarianship'43 and also, in the knowledge there exists at least one 'Trekkie' among the law librarianship fraternity, the conference report 'Law Libraries: the Next Generation or Two Librarians Boldly Go...."44

Christine had a great ability to attract authors to write on a vast array of relevant topics. She also used guest editors on occasions to very great effect. The Special Issue on Networks from 1995, edited by David Byrne, was an excellent example of how a dedicated issue could work and there were fourteen articles published on the defined theme that was emerging and would have far reaching implications for the industry. As David put it in opening lines of his guest editorial:

It seems that you cannot open a newspaper or journal nowadays without being bombarded with discussion of the Internet or Information Superhighways. In this issue of The Law Librarian the broader issue of electronic networking is considered from a number of different perspectives. ${ }^{45}$

Prior to that, the increasingly relevant area of environmental law was featured with six articles appearing June 1994. However, as common to all editors responsible for commissioning material, some frustrations were evident and on one occasion not even the national library and the relevant government department evaded the Editor's scorn!

Many months ago this issue of the Law Librarian was planned to be wholly devoted to environmental affairs. In the intervening months, of course events have endeavoured to change this plan. Contributions had been promised from a number of sources, including a useful briefing on the environmental information services offered by the British Library, which the Editorial Board thought would be of great interest to readers. Unfortunately, due to the vagaries of staff changes at the $B L$, they were unable to supply us with an article, We have also been let down by the Department of Environment itself! In all four of the promised contributions have failed to materialise. The editor therefore apologies for the relatively small number of articles on the environment. ${ }^{46}$

Christine Miskin's tenure as Hon. Editor came to a close with the last issue of 1995 which she co-edited with Laurence Eastham who then took on the role in a new capacity, that of a paid editor rather than on an honorary basis. Laurence's first editorial acknowledged the everchanging nature of the law librarianship profession, when he declared:

This issue is the product of two editors and is the last for which Christine Miskin is responsible (even jointly). She has already been made aware of the appreciation of the [BIALL] Council and the Editorial Board but it is only right that her immense contribution to the magazine over the last five years should be acknowledged in these pages too. In recognition of her departure, the Editorial Board has decreed that this issue shall be printed in black type. ${ }^{47}$

The journal (or 'magazine' as Laurence sometimes tended to call it!) continued to evolve and some issues contained more articles than before - volume 27(2) for June 1996 was particularly unusual with 21 pieces relating to the theme of the use and provision of non-legal information services and outsourcing. In addition, there were sections on 'InfoTech' matters, current awareness and book reviews. Indeed, as time went on the number of book reviews increased. Some of Laurence's editorials became something of a feature in themselves. In his Editorial for the issue for September 1997 be berated legal publishers. Over four pages he discussed the pressures from the perspectives of both librarians and publishers and by the end he drew an analogy with marriage guidance,

that publishers and law librarians were apparently a marriage made in Heaven.... [but that] ... a successful marriage is hard work. Both sides need to concentrate on communication with mutual respect - and perhaps the legal publishers need to concentrate particularly hard if they are to regain some of the trust that seems to have been lost.

\section{A CHANGE OF NAME TO: LEGAL INFORMATION MANAGEMENT}

Laurence and the Editorial Board oversaw arguably the most dramatic change in the journal's history. The content of The Law Librarian had often assessed the role of law librarians and those working in the legal information industry. However, by the December 1999 issue, and with BIALL having reached a 30 -year anniversary it was time once again to look at the direction of the profession. The Editorial Board considered changes to the journal and also to its name in order to try to better 
represent the role of those working in the industry. As the Editor pointed out:

For over 30 years, BIALL has produced its journal under the title of The Law Librarian. But as the traditional role of the Law Librarian changed to take account of the diversity of sources available and increasing responsibilities for information provision and management, many law librarians became disenchanted with that as a job title and changed their titles to become legal information managers or similar. ${ }^{48}$

The Editorial Board was conscious that there were many people operating in the field of legal information provision, such as knowledge management workers and professional support lawyers, who are unlikely to consider a journal with the name The Law Librarian. ${ }^{49}$

A call from the journal to readers to express their views yielded a disappointing number of comments - just 3 in fact - but an insert in the BIALL Newsletter that was sent out to the membership brought over 100 responses. The upshot of discussion at the Editorial Board and BIALL Council, and following the consultation, meant that the spring 200I issue saw a change of title from The Law Librarian to Legal Information Management. This was a big step for the journal and a significant marker not only in its journey but also as a reflection of the state of the profession at that point in time.

In the detailed survey of views, it was noted that The Law Librarian was the least popular option. Legal Information Management, with the abbreviation LIM, was the preferred name.

A new title was just one of the changes introduced. A redesign of the cover and a change to the internal appearance was considered vital to its appeal. The new style and presentation often featured photographs of the authors (although some had appeared previously) and articles commenced with abstracts. Sub-titles were bolder which gave the appearance of a softer, more reader-friendly product. However, the most important aspect of the journal, the quality of the content, continued to be high and the first issue in the new era was devoted to the topical matters of human rights and UK devolution. The first article under the new title was written by a certain Keir Starmer, now the newly elected Leader of the Labour Party and previously Shadow Brexit Secretary; and at the time of the article, a barrister at Doughty Chambers. In his article he was outlining 'The European Convention on Human Rights and the Human Rights Act I998.' [(200I) I(I) LIM, 3-9].

2002 brought Laurence's time as editor to an end and he reflected, 'The biggest lesson I have learnt in my years as Editor is not to underestimate the very considerable skills of legal information professionals. 50 Laurence went on to become editor of another journal in a related field, Computers \& Law.

Christine Miskin was then recruited by BIALL and therefore was both Laurence's successor as well as his immediate predecessor! Christine took up the task for a second time with much enthusiasm. Her first issue (autumn, 2002) examined the surprising acquisition of the online service Lawtel by Sweet \& Maxwell and focused on the papers delivered at the BIALL Annual Conference which had returned to Liverpool that summer having been the venue for the first conference held in 1970.

\section{A MOVE TO CAMBRIDGE UNIVERSITY PRESS}

The early part of Christine's tenure as Editor was marked by another significant moment in the journal's history, this time a change of publisher from Sweet \& Maxwell to Cambridge University Press (CUP). This was a significant shift for the journal. Sweet \& Maxwell was a commercial, practitioner-related legal publisher that served the journal very well, while CUP was a more traditional academic publisher. In some senses and on reflection, this might appear to be at odds with the recent shift in title to better reflect the law firm sector. However, the CUP have proved to be excellent partners for LIM and the resulting product and its marketing have been handled in a very professional manner.

The Editorial Board prepared the way for the transition and it proved a timely moment to review the strategic planning for the journal. As Christine noted in the inaugural issue under the new publisher, following a lengthy discussion by the Board, it "was agreed that our mission statement was "to be the journal of choice to all

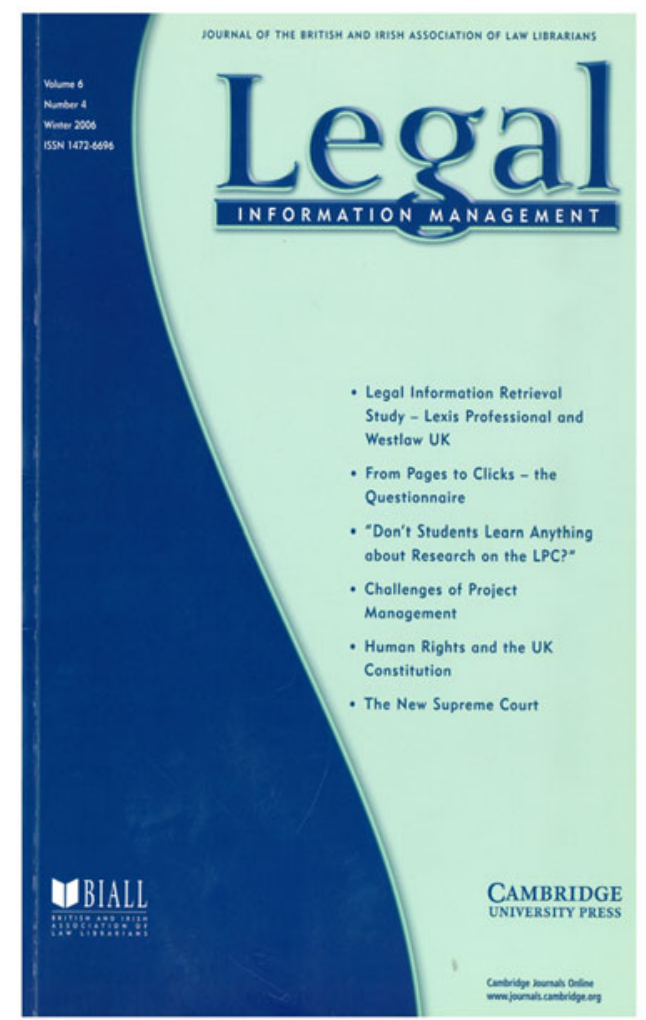

Figure 3: A cover of Legal Information Management from 2006. 
British and Irish legal information workers" and that topics to be included would be of interest to all categories of readers - in law firms, academia, professional organisations, government or the courts. ${ }^{51}$

The journal continued to develop with content often running to some 80 or so pages per issue and the range of subjects covered was impressive. Christine developed further the themed approach and there were offerings under headings such as 'Multi-Site Management of Library and Information Services'52, 'Far Eastern Sources of Law and Legal Information'53, 'Law Librarianship in the $21^{\text {st }}$ Century'54 and 'Legal Information, Cat, Class and Metadata'. ${ }^{55}$ A regular feature with an international viewpoint at this time was 'From our own correspondent'. By now extensive referencing and footnoting was a stronger feature and articles included biographies of the authors. From 2007 keywords reflecting the subject matter were in evidence beneath the abstracts for each article. During this period the front cover altered again.

After a highly successful second editorial stint with the journal, Christine Miskin stepped down as Editor in 2011 after a commitment to the journal of 14 years in total across her two tenures (1990-1995 and 2002-20II). Her editorial achievements, and those of her predecessors, were extraordinary and so it was with much fear and trepidation that the current editor took over the role. In my previous capacity as BIALL President, it was particularly gratifying to be able to honour Christine's achievements at the Association's Annual Dinner, held in Newcastle in

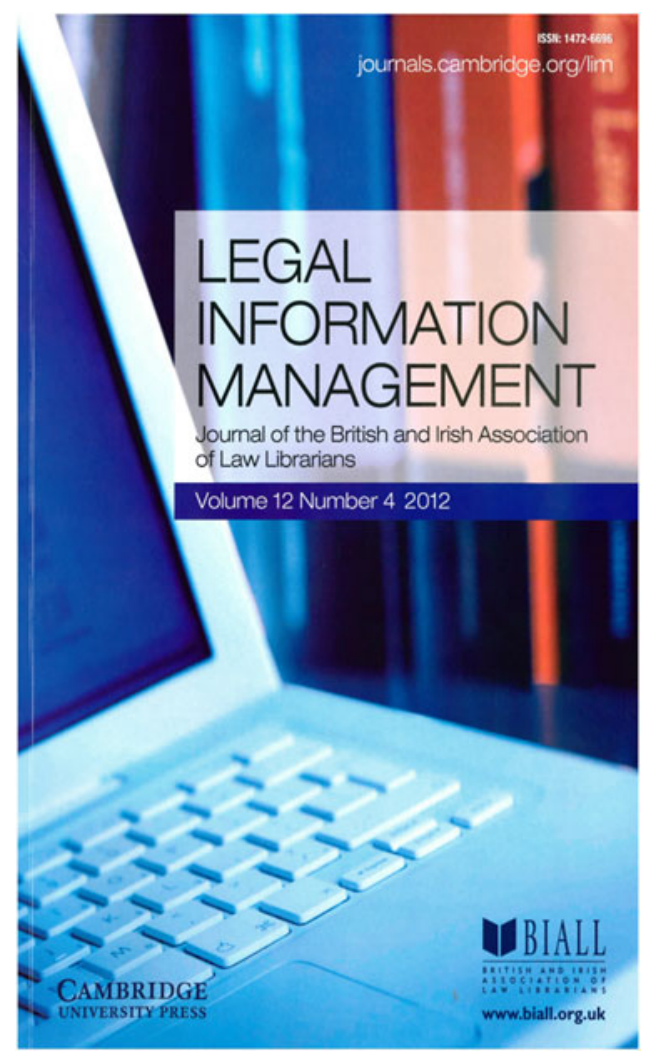

Figure 4: The cover of LIM in 2012.
20I I, by conferring upon her Life Membership of BIALL in recognition of her commitment and dedication.

For my part, I do not intend to write much in relation to the rather more modest achievements of recent years since 20II. Some of the regular features of the past have continued as before - such as the use of themes, featured articles from colleagues overseas, the publication of the results of the annual SLS/BIALL Academic Law Library Survey, many of the BIALL Conference papers and the inclusion of the biennial Willi Steiner Memorial Lecture. Themes that have been included are 'The Irish Legal System, Law Libraries and legal Information'56, 'Legal Literature: Unlocking Access'57, 'Legal Information and Aspects of Devolution'58, German Law and Legal Information'59, 'Law, Gender and Sexuality: Sources and Methods in Socio-Legal Research'60, 'Ways of Working'6I and 'Moys Classification' 62.

The summer issue of 2019 was dedicated to a celebration of 50 years of BIALL with a special anniversary issue $^{63}$ and the winter LIM included the 7th Willi Steiner Memorial Lecture that was delivered by Lady Brenda Hale, the President of the Supreme Court of the United Kingdom, entitled 'The Changing Legal Landscape'. 64

The Editorial Board agreed to move to a more nonpictorial cover that used the BIALL blue colours and showed a clean, simplified approach (as shown in Figure 8). Some other presentational aspects altered, such as the BIALL logo which the Association had recently refreshed. When the winter 2016 issue was published the new and improved look was complete. Judging by the front cover, it could be said that the image of LIM today could be considered to have a more 'academic look' but the content continues to be relevant across the profession including the commercial sector.

\section{LIM TODAY}

One of the most striking aspects of journal production today is the obvious one - the way journal publishing has shifted towards electronic access. In this regard, Cambridge University Press have promoted and marketed LIM as one of their journals on the Cambridge Core platform that allows easy access for CUP subscribers and, with reference to LIM, available to BIALL Members. It opens up the journal to a global audience. With the data that can be gathered, electronic access also allows the Editorial Board to monitor progress with the journal in terms of readership, circulation and levels of usage of the content. The journal is not only on CUP's Cambridge Core service but has for some years been available via the two prominent legal information publishers, LexisNexis and Westlaw, as well as the US periodical specialist service, HeinOnline.

\section{SOME RECENT TRENDS}

One of the advantages of electronic access to journal content over the print format is that it is possible to follow 


\section{Chairs of the Editorial Board}

$\begin{array}{ll}1969-1995: & \text { The Hon. Editor } \\ 1995-1997: & \text { Claire Booth } \\ 1997-2000: & \text { Kate Hodgson } \\ 2000-2003: & \text { Jonathan Gordon-Till } \\ 2003-2006: & \text { Caroline Mosley } \\ 2006-2009: & \text { Janice Edwards } \\ 2009-2012: & \text { Sarah Froggatt } \\ 2012-2016: & \text { Dunstan Speight } \\ 2016-2019: & \text { Loyita Worley } \\ 2019- & \text { Sinéad Curtin }\end{array}$

Figure 5: Chairs of the Editorial Board.

trends in both circulation and usage. Since CUP began publishing the journal in 2004 the trend in general has been towards a steady increase in terms of full text downloads, as Figure 6 (below) demonstrates. CUP's Cambridge Core platform, and its forerunner Cambridge Journals Online (CJO), have revealed considerable data in this regard.

The growth of the internet and technological developments relating to accessibility of ejournal content over the period from 2004 to 2019 is an important factor in evaluating the upward trend. Where LIM is concerned the journal is seen to be growing rather than declining and this is comforting.

Of particular note, there was a significant jump in usage for the Cambridge Core platform in 2019. This is clearly reflected in the statistics for LIM whereby the full text downloads went from a steady state of 12,215 in $2016,12,200$ in $2017,12,882$ in 2018 to 20,348 in 2019.

In 2015 LIM was accepted into the Emerging Sources Citation Index (ESCl), so 'Web of Science' began to track citations to the journal from 2016. In that time, an increase in the number of citations has also followed the upward trend: 858 in 2016, 837 for 2017, 1,047 in 2018 and 1070 in 2019.

\section{THE EDITORIAL BOARD}

This article has tended to follow the development of the journal in terms of content, appearance and the direction of travel through the eyes of the editors. At this point it is important to remark on the commitment and input of the journal's Editorial Board. The Board was established in 1977 on the separation of editorial responsibility for The Law Librarian from BIALL's Publications Committee. ${ }^{65}$ The Chairs of that committee have played a very significant role in the progress of the journal throughout its history. They have been responsible for supporting and overseeing the work of the editor and ensuring that the content is appropriate; that standards are maintained; that contracts with the publishers have been assessed and considered appropriately in consultation with BIALL Council; and that the Board's membership has been maintained and managed. Board members have been crucial in helping with content, persuading (cajoling!) potential authors, coordinating book reviews and in showing huge commitment to the task of proof-reading content, all of which is time-consuming and done on a voluntary basis. Many of these Board members have played active roles over lengthy periods of time.

In the early years of the journal, before the BIALL Newsletter was launched, particular praise should be singled out with reference to the BIALL Hon. Secretaries for providing the regular flow of official notes that were such and important feature of the The Law Librarian as a service to the members and the profession. Those who have been indexers for the journal and those who have compiled, and continue to contribute, the current awareness sections have also played a very significant role in the history of the journal. In this regard, specific mention

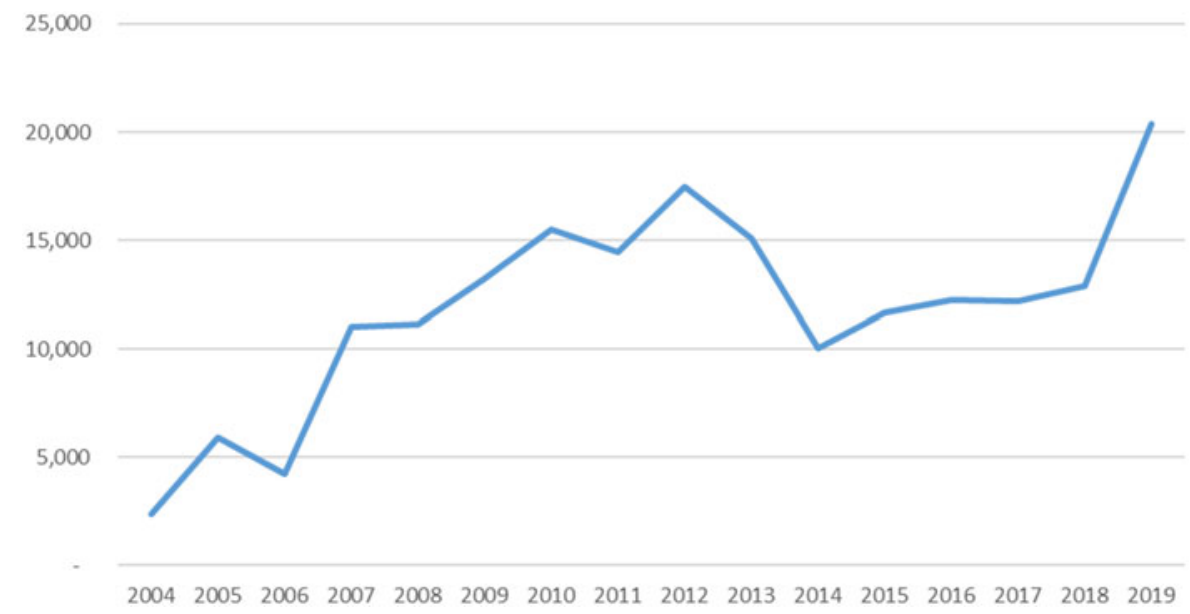

Figure 6: Long term trend - the number of full text downloads for LIM over the period 2004 to 2019. 


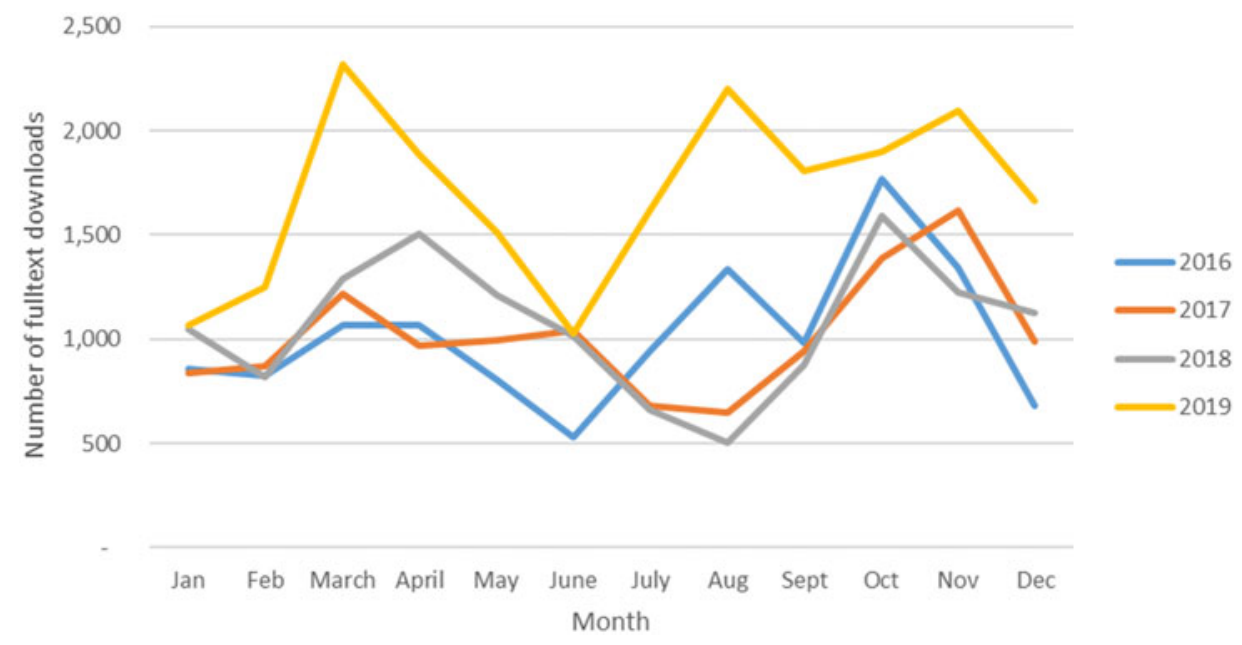

Figure 7: Recent statistics from Cambridge Core concerning usage data from 2016 to 2019.

should be given to two particular Board members who have made longstanding contributions to the current awareness (CA) section, both from the Institute of Advanced Legal Studies Library. Jill Newell, who was involved between 1985 and 1997, and again from 1998 to 2000, and Katherine Read who continues to deliver prompt copy of the CA each quarter, with assistance from colleagues, and has done so for many years.

In a similar way to the running of BIALL's Annual Conference, the publishing of the BIALL Newsletter and other regular services offered by the Association, over the past 50 years the journal has been one of the 'deliverables' and one that has consistently been a benefit for members of BIALL. Many people have played a vital role over the past fifty years in ensuring that the journal has remained a relevant and appropriate publication for the Association.

\section{THE FUTURE AND CHALLENGES}

With reference to the statistical trends mentioned above, for the time being at least, the journal is on an upward trajectory. The future of LIM appears to be bright. But there is little room for complacency. There are challenges and the journal publishing world is moving through unprecedented changes with the growth of the Open Access agenda, the recent initiative 'Plan S' (supported by cOAlition $\mathrm{S}$, an international consortium of research funders) and uncertainty around changing publishing models and what that means for relatively small associations, compared to the larger publishers, that produce a journal - like BIALL.

BIALL as an association has seen a drop in membership in recent years. The focus again is, as always, on an ever-changing profession. There are many fewer defined law librarians working in the academic sector. Subject specialists often work across disciplines which may include law but often alongside other subjects in the humanities and social sciences. Professionals working in the law firm sector, and others parts of the commercial world, may not view BIALL, and therefore LIM, as relevant given the wider range of responsibilities that their roles now encompass. Keeping the journal meaningful will be the challenge - as, perhaps, it always has been throughout its fifty year history.

Attracting potential authors to write for LIM is likely to become more challenging in the future. Arguably, today, people lead busier lives than ever, both personally and professionally. The old adage, 'time is money' is highly relevant with working lives dedicated to the day job; writing an article for a journal maybe a luxury in terms of time available. The art of the editor is to persuade people to write, drawing attention to the opportunities for demonstrating continuing professional development (CPD) and making valid contributions to the profession at large.

LIM has often benefited from articles authored by academic writers but in the modern teaching and research world, dynamics such as the REF (Research Excellence Framework) mean that colleagues working in the higher education environment are less likely to devote precious time to writing for a journal that is part practitioner, part academic, and arguably less immediately obvious and visible from a REF-perspective. The emphasis on altmetrics - the method of tracking and demonstrating the reach, influence and impact of a piece of research means that academic writers will always tend to prefer to publish with revered, peer-reviewed academic journals. During the middle 2000s, here had been an intention to publish one peer-reviewed article per LIM issue, but this proved difficult to sustain. Today, articles in LIM can be peer-reviewed on request, or at the discretion of the editor, and material can be REF-able but, for better and for worse, the journal remains essentially a practitioners' journal and should remain that way.

Nevertheless, the journal's growing presence in the market (as demonstrated in the graphs included in this article) reflects a positive aspect of its performance, and it benefits greatly from the support of a distinguished and 


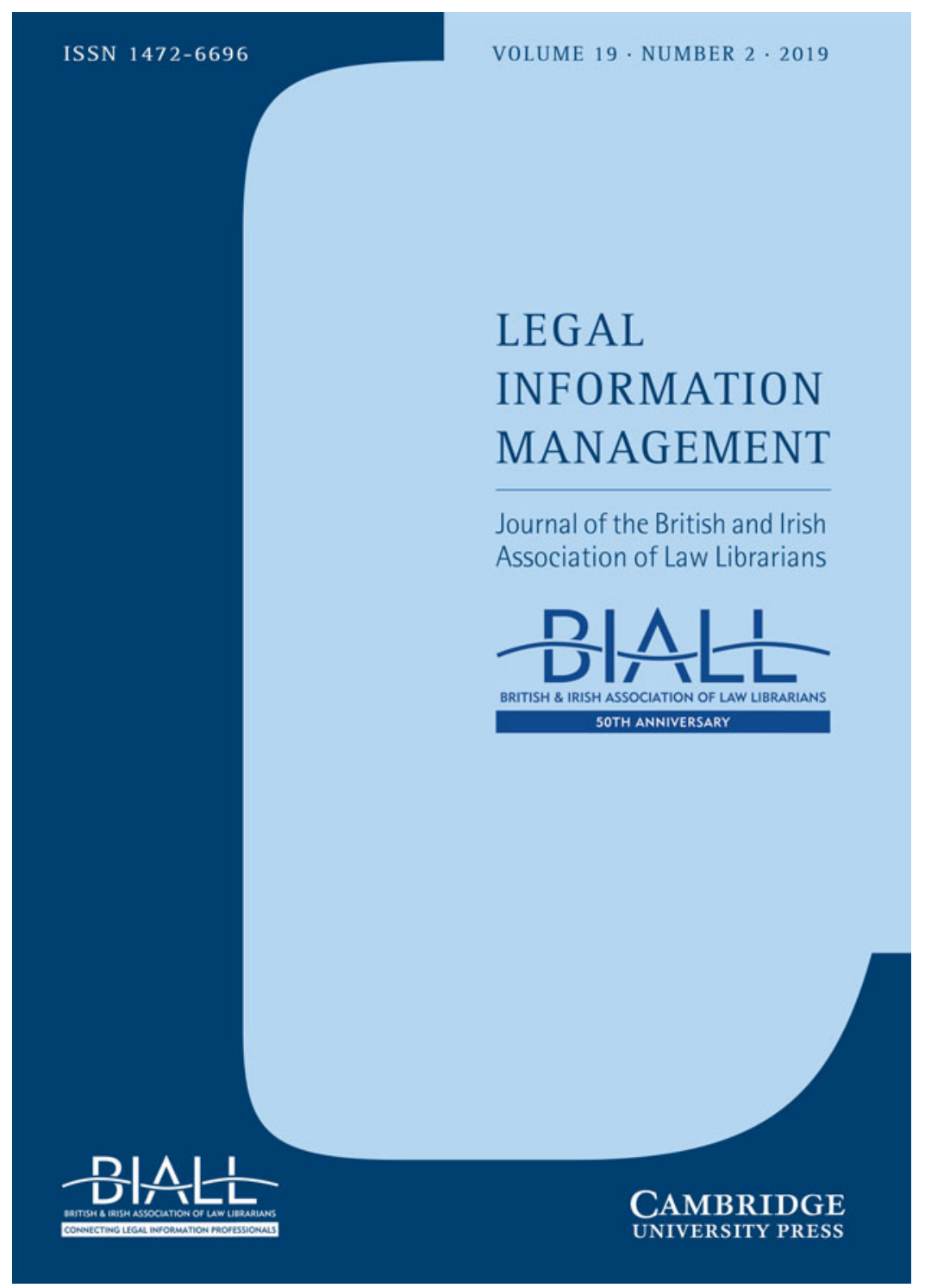

Figure 8: The cover of the special issue of LIM that celebrated BIALL's 50th Anniversary.

longstanding publisher, ie. CUP. It is notable that CUP has seen fit to take a second journal in the field, that has a similar background and mission, and that is the International Journal of Legal Information - the journal of the International Association of Law Libraries (IALL). CUP's growing portfolio of law and law-related journals means that LIM is in good hands for the foreseeable future.

Nevertheless, in the ever-changing world of journal publishing, with different publishing models being developed to accommodate the open access agenda that is associated with academic research and writing, so practitioner journals that are based on the traditional subscription approach could become more vulnerable. Journals like LIM primarily serve the interests of the membership of the organisations to which they are attached. In this emerging 'pay-to-publish' environment, association members would be unlikely to want to pay the necessary fees to in order to publish (given that support funding and research grants, would be unavailable). This would probably leave the publishing vehicles for many learned societies and smaller associations, like BIALL, in an uncertain place. The next two to three years will see much change in the landscape of journal publishing and it remains to be seen what the impact will be on LIM.

\section{CONCLUDING COMMENTS}

First and foremost, LIM is the journal of the British and Irish Association of Law Librarians and its mission remains, as before, to be a vehicle that offers BIALL members a product that describes and discusses issues of professional interest in the law library, legal information field. This editor, and doubtless future LIM editors, will endeavour to continue attracting authors from all sectors 
of the law library and legal information management world in order to reflect the business of our dynamic and fast changing industry.

Feedback about the content published, and opportunities for future content, is infrequent but it is always extremely welcome when it is forthcoming. All feedback is helpful to the editor in considering future options for themes and individual articles that would be of likely interest to the readership of the journal. But as Barbara Tearle once wrote when she was Hon. Editor,

If there are subjects or features which you would like to see covered, please write to me, but do not be surprised if you are then asked to write the article! ${ }^{16}$

\section{Footnotes}

' See: David Wills, 'Editorial and Introduction' (2019) 19(2) Legal Information Management, 73-74.

${ }^{2}$ Mary Blake, A History of the British and Irish Association of Law Librarians 1969-1999 (BIALL, 2000), 5 I.

${ }^{3}$ Elizabeth M. Moys 'Editor's Notes'. (1970) I(I) The Law Librarian, 2.

${ }^{4}$ Mary Blake, A History of the British and Irish Association of Law Librarians 1969-1999 (BIALL, 2000), 52.

${ }^{5}$ Donald Daintree, 'Welcome'. (1970) I(I) The Law Librarian, I.

${ }^{6}$ Ibid.

${ }^{7}$ A.H. Hudson, 'The Law in the Next Decade' (197I) 2(I) The Law Librarian, 6-7.

${ }^{8}$ Karl F Kreuzer, 'Law Libraries and Law Collections in the Federal Republic of Germany' (197I) 2(3) The Law Librarian 39-42.

9 Don Daintree, 'The Beginnings of Legal Journalism' (1973) 4(I) The Law Librarian 5-8.

${ }^{10}$ Nicholas J. Harrison, Problems of Non-Legally Qualified Librarians in Law Libraries: a Symposium Edited by Nicholas J. Harrison 1973 4(2) The Law Librarian 2I-23.

I' G.H. Ballantyne, 'The Provision of Books in the Courts of Scotland' (1975) 6(2) The Law Librarian 25.

12 Michael Bacon, 'Computers and Legal Publications' (1975) 6(3) The Law Librarian 38-39.

${ }^{13}$ Don Raistrick, 'Miss E.M. Moys' (1977) 8(3) The Law Librarian 35.

${ }^{14}$ A quote from: Mary Blake, A History of the British and Irish Association of Law Librarians 1969-1999 (BIALL, 2000$), 52$.

${ }^{15}$ Barbara Wells, 'Editorial' (1984) 15(3) The Law Librarian 35.

${ }^{16}$ Angela Scott, 'Private Libraries in the City' (1978) 9(I) The Law Librarian 3-4.

${ }^{17}$ Christine Miskin, 'The Solictors' Law Firm Library' (1978) 9(3) The Law Librarian 4I.

${ }^{18}$ Diane Raper and Lillian Stephenson, 'The Use of Prestel in a Solicitor's Law Firm in the City' (198I) I2(I) The Law Librarian 4-6.

${ }^{19}$ Muriel Anderson, 'Automation in the Law School Library' (1980) II(I) The Law Librarian II-I4.

${ }^{20}$ Gillian Bull, 'Technical Developments in Legal Information Retrieval: a Guide for BIALL Members' 1980 I I(2) The Law Librarian 34-40.

${ }^{21}$ Susan Broad, 'The Computer in Legal Education' (1980) II (2) The Law Librarian 4I-42.

22 Bernard Houghton, 'Legal data online' (198I) 12(2) The Law Librarian 3I-33.

${ }^{23}$ David Thomas, 'The 'Paperless Law Library' in the United States' (1986) 17(1) The Law Librarian I3-17.

${ }^{24}$ Paul Burton, 'The use of Microcomputers in libraries and information services' (1986) 17(I) The Law Librarian 18-23.

${ }^{25}$ Mel Collier, 'POLIS: the Parliamentary Online Information Systems' (1986) 17(I) The Law Librarian 32-26.

${ }^{26}$ Barbara Wells, 'Editorial' 1984 I5(3) The Law Librarian 35.

${ }^{27}$ Christine Miskin, 'Perception and Projection of the Library's Image in the Law Firm' (1987) I8(I) The Law Librarian 2-6.

${ }^{28}$ Sylvia Webb,'Managing to improve: effective management of library and information services' (I987) $18(\mathrm{I})$ The Law Librarian 7-9.

${ }^{29}$ Hilary Hammond, 'Interpersonal skills in operational management' (1987) I8(I) The Law Librarian II-12.

${ }^{30}$ I.T. Smith, 'Industrial relations at work - law and literature' (1987) 18(I) The Law Librarian 2I-24.

${ }^{31}$ Jennifer Rooke, 'Strategy for the Nineties: the Law Firm Perspective' (1990) 2I(I) The Law Librarian 3I-33.

${ }^{32}$ George Woodman, 'Legislation in Northern Ireland' 1987 I8(2) The Law Librarian 46-49.

${ }^{33}$ David Este, 'The library and the book trade' (1988) 19(I) The Law Librarian I5-2I.

${ }^{34}$ Andrew Green, 'Some Issues in Legal Indexing' (1989) 20(I) The Law Librarian 7-14.

${ }^{35}$ Margaret Byrne, 'Law libraries in Ireland' (1990) 21 (2) The Law Librarian 53-58.

${ }^{36}$ Guy Holborn, 'Using TINlib for Cataloguing at Lincoln's Inn (1990) 2I(2) The Law Librarian 67-69.

${ }^{37}$ Christine Miskin, 'Editor's Notes' (199I) 22(I) The Law Librarian I.

${ }^{38}$ Ibid.

39 Pat Walker, 'This Little Piggy Went to Market: a Case Study in Agricultural Law' (1991) 22(3) The Law Librarian I35-I38.

${ }^{40}$ Fenella Lacey, 'Developing the Video collection in the Wolverhampton Polytechnic Law Library' 1992 (23(I) The Law Librarian 39-40.

${ }^{41}$ Sheila Doyle, 'The Barrington Manuscripts: from Durham to the Inner Temple' (1992) 23(2) The Law Librarian 66-74.

${ }^{42}$ Geoffrey Rowland, 'The Bailiwick of Guernsey' (1992) 23(4) The Law Librarian I8I-I88. 
${ }^{43}$ John Jeffries, 'From Cavalry to Courts - Impressions of Law Librarianship' (1992) 23(2) The Law Librarian 91-93.

${ }^{44}$ Liz Carpenter and Lyn Burden, 'Law libraries: the next generation, or two law librarians boldly go...' (1993) 24(3)

The Law Librarian 143-144.

45 David Byrne, 'Editor's Notes' (1995) 26(I) The Law Librarian 245.

${ }^{46}$ Christine Miskin, 'Editor's Notes' (1994) 25(2) The Law Librarian 57.

${ }^{47}$ Laurence Eastham, 'Editor's Notes' (1995) 26(4) The Law Librarian 478.

${ }^{48}$ Laurence Eastham, 'Editor's Notes' (200I) I(I) The Law Librarian 2.

${ }^{49}$ Laurence Eastham, Editor's Notes' (2000) 3I(I) The Law Librarian 2-3.

${ }^{50}$ Laurence Eastham, 'Editorial' (2002) 2(2) Legal Information Management 2.

${ }^{51}$ Christine Miskin, Editorial' (2004) 4 Legal Information Management 3-4.

52 (2005) 5 Legal Information Management 9-24.

53 (2007) 7 Legal Information Management 84-92.

${ }^{54}$ (2008) 8 Legal Information Management 4-50 and (2008) 8 Legal Information Management 84-104.

55 (2010) 10 Legal Information Management I-47.

${ }^{56}$ (2011) II Legal Information Management 150-210.

${ }^{57}$ (20I2) I Legal Information Management I58-202.

58 (2013) I3 Legal information Management I34-16I.

${ }^{59}$ (2014) 14 Legal information Management 100-132.

${ }^{60}$ (2015) I5 Legal Information Management 2-50.

${ }^{61}$ (2017) 17 Legal Information Management 5-23.

${ }^{62}$ (2018) I8 Legal Information Management 128-146.

${ }^{63}$ (2019) I9 Legal Information Management 73-121.

${ }^{64}$ (2019) 19 Legal information Management 217-223.

${ }^{65}$ Donald Raistrick, 'Editor's Notes - Editorial board' (1977) 8(3) The Law Librarian 46.

${ }^{66}$ Barbara Wells, 'Editorial' (1984) I5(3) The Law Librarian 35.

\section{Biography}

David Wills has worked at the Squire Law Library at the University of Cambridge for more than 26 years and since 1996 he has held the position of Squire Law Librarian. He has also had a variety of roles at senior management level at Cambridge University Library. He has been an active member of the British and Irish Association of Law Librarians (BIALL) since 1998, a former President of the Association (in 2010/20II) and was awarded Life Membership in 2017. Since 20II David has been the commissioning editor for Legal Information Management. 